
\title{
25 Research Square \\ Effect of Intravenous Cell Therapy In Rats With Old Myocardial Infarction
}

\author{
Xian-Liang Tang \\ University of Louisville \\ Marcin Wysoczynski \\ University of Louisville \\ Anna M. Gumpert \\ University of Louisville \\ Yan Li \\ Beijing University of Chinese Medicine \\ Wen-Jian Wu \\ University of Louisville \\ Hong Li \\ University of Louisville \\ Heather Stowers \\ University of Louisville \\ Roberto Bolli ( $\nabla$ rbolli@louisville.edu ) \\ Louisville Metro Public Health and Wellness https://orcid.org/0000-0002-9160-8614
}

\section{Research Article}

Keywords: Cell therapy, stem cells, fibrosis, inflammation, intravenous, ischemic cardiomyopathy, myocardial infarction, repair

Posted Date: July 20th, 2021

DOl: https://doi.org/10.21203/rs.3.rs-680510/v1

License: (c) (i) This work is licensed under a Creative Commons Attribution 4.0 International License. Read Full License

Version of Record: A version of this preprint was published at Molecular and Cellular Biochemistry on November 16th, 2021. See the published version at https://doi.org/10.1007/s11010-021-04283-2. 


\section{Abstract}

Mounting evidence shows that cell therapy provides therapeutic benefits in experimental and clinical settings of chronic heart failure. However, direct cardiac delivery of cells via transendocardial injection is logistically complex, expensive, entails risks, and is not amenable to multiple dosing. Intravenous administration would be a more convenient and clinically applicable route for cell therapy. Thus, we determined whether intravenous infusion of three widely used cell types improves left ventricular (LV) function and structure and compared their efficacy. Rats with a 30-day-old myocardial infarction (MI) received intravenous infusion of vehicle (PBS) or 1 of 3 types of cells: bone marrow mesenchymal stromal cells (MSCs), cardiac mesenchymal cells (CMCs), and c-kit-positive cardiac cells (CPCs), at a dose of $12 \times 10^{6}$ cells. Rats were followed for 35 days after treatment to determine LV functional status by serial echocardiography and hemodynamic studies. Blood samples were collected for Hemavet analysis to determine inflammatory cell profile. LV ejection fraction (EF) dropped $\geq 20$ points in all hearts at 30-day after $\mathrm{MI}$ and deteriorated further at 35-day follow-up in the vehicle-treated group. In contrast, deterioration of EF was halted in rats that received MSCs and attenuated in those that received CMCs or CPCs. None of the 3 types of cells significantly altered scar size, myocardial content of collagen or CD45-positive cells, or Hemavet profile. This study demonstrates that a single intravenous administration of 3 types of cells in rats with chronic ischemic cardiomyopathy is effective in attenuating the progressive deterioration in LV function. The extent of LV functional improvement was greatest with CPCs, intermediate with CMCs, and least with MSCs.

\section{Introduction}

Ischemic cardiomyopathy, a sequela of myocardial infarction (MI), promotes adverse left ventricular (LV) remodeling, chamber dysfunction, heart failure, and mortality. Recent studies suggest that cell therapy is a promising option for repairing the injured heart, one that has attracted considerable interest over the past two decades. However, it still remains unclear what the best cell type is for the treatment of ischemic cardiomyopathy, and how and when cells should be delivered after MI. As the field has progressed, it has become clear that the beneficial impact of cell therapy is likely the result of paracrine effects, rather than new cardiomyocyte regeneration from differentiation of the transplanted cells [1-3]. Our previous studies in various preclinical models have shown that administration of c-kit-positive (c-kit ${ }^{\mathrm{POS}}$ ) cardiac cells (CPCs) in mice [4, 5], rats [6-10], and pigs [11] and cardiac mesenchymal cells (CMCs) in mice [12] after $\mathrm{MI}$ alleviates LV dysfunction and remodeling without significant new myocyte regeneration. The mechanism(s) underlying the functional benefits of CPCs and CMCs are unknown, but likely multifactorial, and may include reduction in myocardial collagen (as demonstrated in our previous studies with CPCs and CMCs $[6-9,12])$, and/or pro-angiogenic, anti-apoptotic, and anti-inflammatory actions [1-3].

Given that exogenous cells do not engraft and that cardiomyocyte differentiation is not a major contributor to their functional benefits, delivery of cells to the myocardium may not be a prerequisite for therapeutic efficacy. Systemic delivery of cells via intravenous administration would be an ideal delivery 
route because it would be simple, inexpensive, safe, widely applicable in almost all clinical settings and in almost all patients with heart failure, and amenable to repeated treatments (which are not possible with the standard transendocardial delivery method) [2,3]. However, preclinical and clinical experience with intravenous. cell injection in heart failure is still scarce. If this mode of delivery were proven effective for favorable risk-adjusted benefits, it would have wide-ranging ramifications for the widespread adoption of cardiac cell therapy in clinical practice.

In the present study, we sought to evaluate the functional benefits of intravenous administration of three cell types that are commonly used for the treatment of heart failure - bone marrow (BM)-derived mesenchymal stromal cells (MSCs), CMCs, and CPCs - to compare their efficacy in promoting cardiac repair in a rat model of chronic ischemic cardiomyopathy induced by a large $\mathrm{MI}[6,9,10,13,14]$.

\section{Materials And Methods}

A detailed Methods section is included in the online supplement.

All animal experiments were performed in accordance with the Guide for the Care and Use of Laboratory Animals published by the US National Institutes of Health (Eighth Edition, Revised 2010) and with the guidelines of the Animal Care and Use Committee of the University of Louisville, School of Medicine (Louisville, KY).

Preparation of cells. The isolation, characterization, and expansion of CPCs, CMCs, and MSCs have been previously described in detail [7-9, 11-14]. Bone marrow was taken from femur and tibia bones for isolation of MSCs and cardiac tissue was used to isolate CPCs and CMCs. Briefly, CMCs were isolated from adult male Fischer 344 rats (4-6 months of age) and expanded for 4-8 passages. C-kit ${ }^{\text {pos }} \mathrm{CPCs}$ were sorted with magnetic beads and phenotyped by fluorescence-activated cell sorting analysis of fixed cells. CPCs expanded in vitro at passages 6 to 8 were used for intravenous administration [7-10].

Surgical procedures and treatment protocol. The rat model of old MI has been described previously $[6,9$, 10]. Briefly, female Fischer 344 rats (age, 4 months; weight $157 \pm 2 \mathrm{~g}$ ) underwent a 2-h occlusion of the left anterior descending coronary artery followed by reperfusion. Thirty days after surgery, the animals were randomly allocated to four treatment groups and received an intravenous injection of vehicle (control) or 1 of 3 types of cells, namely, bone marrow-derived mesenchymal stromal cells (MSCs), cardiac mesenchymal cells (CMCs), and c-kit-positive cardiac cells (CPCs), at a dose of $12 \times 10^{6}$ cells (Fig. 1). Vehicle or cells (in $5 \mathrm{ml}$ of Dulbecco's phosphate-buffered saline) were infused via the jugular vein with an infusion pump at a rate of $1.25 \mathrm{ml} / \mathrm{min}$ for $4 \mathrm{~min}$ in a blinded fashion. Animals were followed up for 35 days after treatment. At 35 days, rats were subjected to hemodynamic studies and euthanized for histologic studies (Fig. 1). Blood samples were collected before and after cell injection for Hemavet analysis to determine the effect of cell injection on inflammatory cell profile.

Echocardiographic studies. All echocardiographic analyses were performed by investigators who were blinded to treatment allocation. Serial echocardiograms were obtained at three time-points: baseline (3 
days before coronary artery occlusion), 30 days after $\mathrm{MI}$ (before treatment, Pre-Rx), and 35 days after treatment (before euthanasia) (Fig. 1A). The echocardiographic studies were performed as described [610, 15] using a Vevo 2100 Imaging System equipped with a 20-MHz transducer. Briefly, rats were lightly anesthetized with $3 \%$ isoflurane. The anterior chest was shaved and the animals were placed in the supine position. A rectal temperature probe was inserted, and body temperature was carefully maintained between $37.0-37.5^{\circ} \mathrm{C}$ with a heating pad throughout the study. Anesthesia was maintained with $1 \%$ isoflurane. Parasternal long-axis 2D images were used for the measurement of LV end-diastolic and endsystolic area (LVAd and LVAs), LV end-diastolic and end-systolic volume (LVEDV and LVESV), stroke volume (SV), cardiac output (CO), and ejection fraction (EF). Measurements were performed according to the American Society for Echocardiography, and were averaged over three consecutive cardiac cycles.

Hemodynamic studies. All hemodynamic analyses were performed by investigators who were blinded to treatment allocation. The hemodynamic studies were conducted 35 days after treatment, just before euthanasia (Fig. 1). The protocol has been described [6-10].

Histologic studies. The protocol for histologic analyses has been described [6-10]. Briefly, all studies were performed on formalin-fixed, paraffin embedded tissues. $4 \mu \mathrm{m}$-thick heart sections were subjected to Masson's trichrome and picrosirius red staining according to manufacturer's recommendations (SigmaAldrich, St. Louis, MO). Immunohistochemistry staining was performed using specific antibodies against CD45 (Abcam, Cambridge, MA) with corresponding secondary antibodies and counterstained with DAPI (Thermo Fisher Scientific, Waltham, MA). Microscopic evaluation of labeled slides was performed using a NIKON Ti2 inverted microscope equipped with DS-Qi2 and DS-Fi3, and monochrome and color cameras, respectively.

Determination of inflammatory cell profile. Peripheral blood was collected at 3 timepoints: baseline (before treatment) and $48 \mathrm{~h}$ and 35 days after administration of cells. Blood samples were collected to EDTA coated tubes and analyzed with Hemavet within $24 \mathrm{~h}$ after collection.

Statistical analysis. All data are expressed as means \pm SEM. Echocardiographic data were analyzed with two-way repeated-measures ANOVA followed by Student's t-tests with Bonferroni correction for intra- and inter-group comparisons, as appropriate. Morphometric, histologic, immunohistochemical, and hemodynamic data were analyzed by one-way ANOVA followed by Student's t-tests with Bonferroni correction for inter-group comparisons [6-10, 16-19]. Mortality was analyzed by the chi-square test. All analyses were conducted with SigmaStat 3.5. $P$ values $<0.05$ were considered significant.

\section{Results}

A total of 56 rats were enrolled and underwent MI. Two of the 56 animals died after MI before group assignment. The remaining 54 rats were assigned to one of the 4 treatment groups (vehicle, MSCs, CMCs, or CPCs). Six of these animals ( 5 in the MSC group and 1 in the CMC group) died after cell infusion. Thus, a total of 48 rats (13 in the vehicle group, 11 in the MSC group, 11 in the CMC group, and 13 in the CPC group) completed the protocol and were included in the final analysis (Supplementary Table I). 
There were no significant differences in body weight among the four groups throughout the experimental protocol (Supplementary Table II). Similarly, there were no significant differences among the groups with respect to LV weight, LV volume, or spleen weight index measured at postmortem examination (Supplementary Table II).

\section{Effect of intravenous administration of cells on LV function measured by echocardiography.} Echocardiographic measurements are summarized in Supplementary Table III; representative echocardiographic images are illustrated in Supplementary Fig. I. Before treatment (30 days after MI, Pre$\mathrm{Rx}$ ), LV ejection fraction (EF) dropped $\geq 20$ points from the baseline value (before $\mathrm{MI}$ ) in all rats (Supplementary Fig. II); the average drop was similar among groups $(-23.0 \pm 0.6,-22.3 \pm 0.4,-24.2 \pm 1.1$, and $-24.2 \pm 1.0$, respectively, in the vehicle-, MSC-, CMC-, and CPC-treated group)(Supplementary Fig. II B). At this time point, LV end-diastolic diameter (LVEDD), area (LVAd), and volume (LVEDV), and endsystolic diameter (LVESD), area (LVAs), and volume (LVESV) were markedly increased from baseline (Supplementary Table III), whereas infarcted LV wall thickness at end-diastole (IWTd) and end-systole (IWTs), fractional shortening (FS), and fractional area change (FAC) were markedly decreased (Supplementary Table III). There were no significant differences among the vehicle, MSC, CMC, and CPC groups in any of these variables, indicating that, before treatment, the severity of post-MI LV remodeling and dysfunction was comparable in all groups.

At 35 days after treatment (Post-Rx), however, the four groups exhibited a different course. As expected [6, $9,10]$, the vehicle-treated group showed no improvement and/or further deterioration of LV function (Fig. 2). Specifically, there was a significant further decline in $\operatorname{LVEF}(-2.1 \pm 0.5 \%, P<0.05$, Fig. 2B) and FAC $(-1.46 \pm 0.63 \%, P<0.05$, Fig. $2 \mathrm{D})$; there was also a nominal increase in LVESV $(+8.73 \pm 4.67 \mu \mathrm{L}, P=\mathrm{NS}$, Fig. 2F) and decrease in stroke volume (SV, $-2.86 \pm 4.12 \mu \mathrm{L}, P=\mathrm{NS}$, Fig. $2 \mathrm{H})$ compared with the pretreatment (Pre-Rx) values at 30 days after MI (Fig. 2).

In contrast to the further deterioration of LV function in the vehicle group, intravenous administration of the three types of cells produced a variable degree of improvement in global LV function (Fig. 2). Administration of MSCs improved LV EF $(+0.50 \pm 0.51 \%$ vs. $-2.10 \pm 0.48 \%$ in the vehicle group, $P<0.01$, Fig. 2A\&B) but failed to significantly alter FAC $(-0.43 \pm 0.36$ vs. $-1.46 \pm 0.63 \%, P=N S$, Fig. 2D), SV (+ $9.81 \pm$ 6.26 vs. $-2.86 \pm 4.12 \mu \mathrm{L}, P=$ NS, Fig. $2 \mathrm{H})$, and LV ESV $(+6.74 \pm 5.26$ vs. $+8.73 \pm 4.67 \mu \mathrm{L}, P=$ NS, Fig. $2 \mathrm{~F})$ compared with the vehicle group.

Administration of CMCs improved both LV EF $(+2.74 \pm 0.43 \%, P<0.01$, Fig. 2A\&B) and FAC $(+2.58 \pm$ $0.32 \%, P<0.01$, Fig. 2C\&D) compared with vehicle; there was also a non-significant decrease in LV ESV (+ $0.28 \pm 6.99 \mu \mathrm{L}, P=\mathrm{NS}$, Fig. $2 \mathrm{~F})$ and increase SV $(+14.58 \pm 8.19 \mu \mathrm{L}, P=\mathrm{NS}, \mathrm{Fig} .2 \mathrm{H})$ compared with the vehicle group. In addition, compared with intravenous infusion of MSCs, intravenous administration of CMCs produced a slightly, but significantly, greater improvement in EF $(+2.74 \pm 0.43 \%$ vs. $+0.50 \pm 0.51 \%$, respectively, $P<0.01$, Fig. $2 \mathrm{~B})$ and FAC (+ $2.58 \pm 0.32 \%$ vs. $-0.43 \pm 0.36 \%, P<0.05$, Fig. $2 \mathrm{D})$.

Intravenous administration of CPCs resulted in superior beneficial effect on LV function (Fig. 2); compared with the vehicle group, there was a marked increase in LV EF $(+6.51 \pm 0.36 \%, P<0.01$, Fig. 
2A\&B), FAC (+ $4.98 \llbracket \pm 0.9 \%, P<0.01$, Fig. 2C\&D), and SV (+27.54 $\pm 7.14 \mu \mathrm{L}, P<0.01$, Fig. $2 \mathrm{G} \& \mathrm{H})$ and decrease in LV ESV $(-7.76 \pm 5.95 \mu \mathrm{L}, P<0.05$, Fig. $2 \mathrm{~F})$. Furthermore, compared with the MSC- and CMCtreated groups, intravenous administration of CPCs produced a greater improvement in LV EF $(P<0.01$ for both the MSC- and CMC-treated group, Fig. 2A\&B), FAC $(P<0.01$ and $P<0.05$, respectively, for the MSCand CMC-treated group, Fig. 2C\&D), and SV ( $P<0.05$ for the MSC-treated group, Fig. 2G).

\section{Effect of intravenous administration of cells on LV function measured by hemodynamic studies. As an} additional assessment of LV function, hemodynamic studies were performed at 35 days after treatment (prior to euthanasia). The hemodynamic parameters are summarized in Fig. 3 and Supplementary Table IV. As shown in Fig. 3, intravenous administration of MSCs did not significantly alter hemodynamic variables, although there was a slight trend toward improvement (Fig. 3 and Supplementary Table IV). Intravenous infusion of CMCs improved significantly LV dP/dt $\max (8337 \pm 150 \mathrm{mmHg} / \mathrm{s}$ in the CMCtreated group vs. $7543 \pm 95$ in the vehicle group, $P<0.01$, Fig. 3D), dP/dt $\min (-7867 \pm 104$ vs. $-7066 \pm 221$, $P<0.01$, Fig. 3D), and dP/dt $\max$ EDV (33.5 \pm 1.8 vs. $27.3 \pm 1.0 \mathrm{mmHg} / \mathrm{s} / \mu \mathrm{L}, P<0.05$, Fig. $3 \mathrm{~F})$, but other hemodynamic parameters were not affected compared with the vehicle group (Fig. 3). Similar to the echocardiographic data, hemodynamic studies also revealed that intravenous administration of CPCs produced superior improvement in LV function; thus, compared with the vehicle group, hemodynamic parameters (SV [136.2 $\pm 4.8 \mu \mathrm{L}$ in the CPC-treated group vs. 117.6 $\pm 4.0 \mu \mathrm{L}$ in the vehicle group, $P<0.05$, Fig. 3B], stroke work [SW, $13.5 \pm 0.4$ vs. $10.7 \pm 0.3 \mathrm{mmHg}^{\star} \mu \mathrm{L}, P<0.01$, Fig. $\left.3 \mathrm{C}\right], \mathrm{dP}^{\mathrm{din}} \mathrm{dt}_{\min }[-7934 \pm 111$ vs. $-7066 \pm 221 \mathrm{mmHg} / \mathrm{s}, P<0.01$, Fig. 3D], EF [54.1 \pm 0.5 vs. $49.8 \pm 0.7 \%, P<0.01$, Fig. $3 \mathrm{E}], \mathrm{dP} / \mathrm{dt}_{\text {max }} \mathrm{EDV}$ $[32.0 \pm 1.2 \mathrm{mmHg} / \mathrm{s} / \mu \mathrm{L}, P<0.05$, Fig. $3 \mathrm{~F}]$, end-systolic elastance $[0.86 \pm 0.02 \mathrm{vs} .0 .73 \pm 0.03 \mathrm{mmHg} / \mu \mathrm{L}, P$ $<0.05$, Fig. 3G], and Tau_w $[10.7 \pm 0.2$ vs. $11.7 \pm 0.2 \mathrm{~ms}, P<0.05$, Fig. $3 \mathrm{H}])$ were significantly improved, although no significant difference was found among the three cell-treated groups.

In summary, two independent methods of functional assessment (echocardiography and hemodynamic studies with a conductance catheter) demonstrated that intravenous administration of three types of cells at a same dose $\left(12 \times 10^{6}\right.$ cells $)$ in rats with chronic Ml yielded variable degrees of improvement in LV function. The extent of LV functional improvement (measured by an array of echocardiographic parameters [Fig. 2] - EF, FAC, ESV, and SV - and hemodynamic variables [Fig. 3] - LV EDP, LV dP/dt, $\mathrm{dP} / \mathrm{dt}_{\max }-\mathrm{EDV}, \mathrm{SV}, \mathrm{SW}, \mathrm{Tau} \_\mathrm{W}, \mathrm{EF}$, and elastance) showed a pattern of a gradient effect, being least with MSCs, intermediate with CMCs, and maximal with CPCs.

LV morphology. Masson's trichrome-stained LV sections were analyzed to determine the risk region, scar size, and volume of viable myocardium. As shown in Fig. 4A, the risk region was similar among the 4 groups. None of the 3 types of cells significantly modified scar size or the volume of viable myocardium when compared with the vehicle group, although there was a trend for MSCs and CPCs to reduce scar size and increase viable myocardium (Fig. 4A).

Picrosirius red-stained LV sections were analyzed to determine the effect of the 3 types of cells on myocardial collagen deposition. As shown in Fig. 4B, the collagen content in both the risk and 
noninfarcted region was not significantly modified by any of the cells given intravenous 35 days prior when compared with the vehicle group, although it tended to be reduced by MSCs and CPCs.

Compared with vehicle, CD45 positive cells tended to be lower in the risk region of rats treated with CMCs and CPCs (Fig. 5A) and in the noninfarcted region of rats treated with all three types of cells (Fig. 5B) than vehicle, but the difference was not statistically significant.

Profile of inflammatory cells in blood. As shown in Fig. 6, blood levels of inflammatory cells including WBCs, neutrophils ( $\mathrm{Ne}$ ), lymphocytes (Ly) as well as the $\mathrm{Ne} / \mathrm{Ly}$ ratio and the platelet/Ly ratio were similar among groups at baseline (before cell infusion). Intravenous administration of the 3 types of cells did not result in significant changes in the inflammatory cell profile at $48 \mathrm{~h}$ or 35 days after cell treatment.

\section{Discussion}

The present study compared the therapeutic effects of intravenous administration of 3 types of cells, i.e., MSCs, CMCs, and CPCs, given at a same dose of 12 million cells, in a rat model of chronic ischemic cardiomyopathy. The salient findings are: i) all 3 types of cells improved LV function but to a variable extent; ii) the degree of improvement was greatest with CPCs, intermediate with CMCs, and least with MSCs (CPCs > CMCs > MSCs); iii) despite their salubrious functional effects, none of the cell types produced significant changes in LV structure (infarct scar size, myocardial collagen content, amount of viable myocardium); and iv) none of the cell types affected the myocardial content of CD45 positive cells or the profile of inflammatory cells in the blood. Taken together, these data provide support for the utility of intravenous cell delivery in chronic ischemic cardiomyopathy, although further studies are needed to identify the optimal dosage and number of administrations and to elucidate the underlying mechanism(s). Several previous investigations have shown LV functional improvement with intravenous MSC infusion in acute MI models in mice $[20,21]$ and rats $[22,23]$ old $\mathrm{MI}$ models in mice [21] and rats [24], and with intravenous CPC infusion in acute MI models in mice [25]. However, to our knowledge, this is the first study to show beneficial effects of intravenous delivery of CMCs and CPCs and the first study to compare three different types of cells head-to-head. Our observations lay the groundwork for future experiments designed to pursue a novel modality of cell delivery - the intravenous route - that could revolutionize the entire field of cell therapy.

In the present study, we used a model of chronic reperfused MI $[6,9,10]$. The rationale for using a model of transient coronary occlusion followed by reperfusion (as opposed to a permanent coronary occlusion) is that, in current practice, almost all patients with acute $\mathrm{Ml}$ are reperfused. Therefore, a reperfused $\mathrm{Ml}$ model is more clinically relevant, and the data have higher translational significance. This rat model is associated with features of chronic ischemic cardiomyopathy. The 2-h coronary occlusion followed by reperfusion caused LV EF to drop $\geq 20$ points in all animals at 30 days after MI (Supplementary Fig. II-B), and this was followed by further deterioration over the ensuing 35 days in control rats (Supplementary Fig. II-A). This progressive decline is reminiscent of that observed in patients with ischemic cardiomyopathy. 
The rationale for testing these 3 types of cells was multifarious. First, MSCs are emerging as promising cells with high potential for therapeutic applications [1,26]. Although intramyocardial MSC injection is a popular approach to repair the heart in preclinical and clinical studies and has yielded positive results [26-36], the efficacy of intravenous administration of MSCs in preclinical models of chronic MI has not been studied extensively. Second, CMCs are a newly-discovered population of cardiac-derived cells [37] and have been demonstrated to improve LV function and remodeling and to reduce myocardial collagen deposition after either intramyocardial injection [12] or echo-guided intraventricular injection [38] in a mouse model of reperfused MI. In the present study, we sought to explore further the therapeutic potential of CMCs given by the intravenous route. Finally, CPCs have been widely studied [2] in various animal models including mice $[4,5,25,37,39-54]$, rats [6-10, 15, 55-71] dogs,[72], pigs [11, 31, 33, 35, 73-75], and humans $[76,77]$ using various delivery routes including intramyocardial injection $[31,33,35,41-43$, $45-54,56-58,61,62,64-68,71,74,76]$, intracoronary infusion $[4-8,11,15]$, and echo-guided intraventricular injection $[9,10,39]$. All animal studies $[4-11,15,25,31,33,35,37,39-75]$ dealing with CPC therapy and a Phase II clinical trial [76] have consistently yielded positive results regardless of species tested, models used, and routes of administration [2]. To our knowledge, however, the effects of CPCs administered by the intravenous route have not been reported. Thus, the present study sought to fill this gap.

An important consideration for widespread adoption of cell therapy in patients is the use of a cell delivery route that is safe, effective, convenient, noninvasive, and repeatable. Mounting evidence indicates that paracrine $[78,79]$ or even endocrine mechanisms mediate the improvement in LV function after cell-based therapy, rather than cell engraftment leading to myocardial differentiation or stimulation of resident myocardial cells to expand and repopulate the heart $[3,80]$. This concept has promoted a change in the approach to the route of delivery of cell-based therapies. The notion is emerging that systemic delivery via intravenous infusion may be a safer, simpler, less expensive, and still effective treatment [3]. In addition, intravenous delivery would have the additional advantage of enabling repeated treatments, which is important considering that the chronic processes leading to progressive LV dysfunction will probably never be cured by a single administration of cells (or any drug) and that repeated injections over time would be necessary for a sustained therapeutic effect $[3,81]$. Therefore, if effective, the intravenous route would offer major advantages over other delivery strategies.

We found that intravenous infusion of 12 million CPCs produced a robust improvement in LV function, as demonstrated both by echocardiographic assessments (Fig. 2) and by hemodynamic studies (Fig. 3). CPCs were more effective than CMCs or MSCs. To compare the potency of these different cells, we used the same dose (12 million cells) for all 3 types of cells. This is the same dose used in our previous studies [9], in which injection of 12 million CPCs into the LV cavity significantly improved cardiac function [9]. Although there was evidence of benefit with all three cell types, the most consistent and profound effects were observed with CPCs, followed by CMCs and then MSCs (Figs. 2 and 3).

As is the case for most cell types studied heretofore [82], the mechanisms underlying the salubrious effects of adult stem cell therapy in vivo remain unclear. In this study, histological analysis showed a 
trend of reduced scar size and increased total LV viable tissue in the rats that received intravenous MSCs and CPCs (Fig. 4A), but the difference was not significant. The fact that administration of CMCs improved LV function without reduction of scar size (Fig. 4) suggests that reducing scar size was not a major factor contributing to the ameliorated LV function. We further assessed collagen deposition in the infarcted and noninfarcted regions and found a trend for reduced collagen content in the noninfarcted region of rats treated with all 3 types of cells (Fig. 4B) compared with vehicle, though the differences did not reach statistical significance. Because the overall contractile performance of the left ventricle after $\mathrm{MI}$ depends primarily on the surviving noninfarcted regions, these observations may partially explain the improvement in myocardial function.

Analysis of CD45 marker expression in the tissue provides information on hematopoietic-derived cells, the vast majority of which are immune cells at these time points. Adult stem cells, such as MSCs [83], possess immunomodulatory properties that may modify immune cell infiltration and recruitment to the infarct region. Therefore, we evaluated the immune cell content of the myocardium by staining heart sections for CD45. Again, we found that administrations of the 3 types of cells resulted in a trend toward reduced CD45 cell content in both the risk region and the noninfarcted region (Fig. 5B) compared with vehicle, but the differences did not reach statistical significance. This mild anti-inflammatory action of cell therapy correlated with the mildly reduced collagen content in the noninfarcted regions and might be responsible in part for attenuating the contractile dysfunction.

Many previous studies [20-23, 34, 84-93] have suggested beneficial effects of intravenous MSCs in various species including mice [20, 21, 85], rats [22, 23, 34, 87], pigs [86, 88-91], and humans [84, 92, 93]. However, almost all of these studies were performed in models of acute nonreperfused MI $[20,21,23,85$, 87-89], acute reperfused MI [86, 90], or subacute nonreperfused MI [34]. Few studies have used a model of chronic MI. Luger et al [21] showed that intravenous administration of $2 \times 10^{6} \mathrm{MSCs}$ in mice 4 weeks post-MI significantly increased LV ejection fraction, decreased LV end-systolic volume, and decreased splenic Ly6Cint/Ly6Ghi neutrophils. Wang et al. [24] reported in rats that intravenous infusion of $5 \times 10^{6}$ MSCs at 3 weeks after MI did not result, 4 weeks later, in improvement in LV function or changes in expression of pro-inflammatory and anti-inflammatory factors in the lung and heart. However, in that study [24] LV function was assessed by measuring LV end-diastolic diameters (LVEDd), LV end-systolic diameters (LVESd), and EF using only 2D short-axis echocardiographic images at the mid papillary muscle level, whereas in our study LV function was evaluated using 2D long-axis images, which we believe is a more appropriate method in models of regional dysfunction caused by MI. Our current study provides novel information regarding the effects of MSCs, CMCs, and CPCs administered intravenous on cardiac function and structure in a model of old MI that mimics the clinical setting.

In conclusion, this is the first study to compare directly intravenous administration of three different cell types in an animal model of chronic ischemic cardiomyopathy. Our results demonstrate that all three types of cells (MSCs, CMCs, and CPCs) are capable of improving cardiac function, albeit with different degrees of potency, with CPCs being the most effective. Further studies will be needed to determine whether the therapeutic efficacy can be enhanced by repeated dosing and to explore the mechanism(s) 
underlying the beneficial effects of intravenous cell therapy. The present results are important because they provide a rationale for pursuing these future investigations.

\section{Declarations}

\section{Acknowledgments}

This study was supported in part by NIH Grants HL113530 and HL-078825.

\section{Disclosures}

None

\section{Author contributions}

Conceptualization: Roberto Bolli; Study design: Xian-Liang Tang and Marcin Wysoczynski; Material preparation, data collection and analysis: Xian-Liang Tang, Marcin Wysoczynski, Anna M. Gumpert, Yan $\mathrm{Li}$, Wen-Jian Wu, Hong Li, and Heather Stowers. The first draft of the manuscript was written by XianLiang Tang and all authors commented on previous versions of the manuscript. All authors read and approved the final manuscript.

\section{Ethical Responsibilities of Authors}

The paper is original and has not been published and is not being considered for publication elsewhere.

\section{Data availability statement}

Supplementary data were included.

\section{References}

1. Bolli R, Solankhi M, Tang XL, Kahlon A (2021) Cell Therapy in Patients with Heart Failure: A Comprehensive Review and Emerging Concepts. Cardiovasc Res. doi:10.1093/cvr/cvab135

2. Bolli R, Tang XL, Guo Y, Li Q (2021) After the storm: an objective appraisal of the efficacy of c-kit + cardiac progenitor cells in preclinical models of heart disease. Can J Physiol Pharmacol 99:129139. doi:10.1139/cjpp-2020-0406

3. Wysoczynski M, Khan A, Bolli R (2018) New Paradigms in Cell Therapy: Repeated Dosing, Intravenous Delivery, Immunomodulatory Actions, and New Cell Types. Circ Res 123:138-158. doi:10.1161/circresaha.118.313251

4. Li Q, Guo Y, Ou Q, Chen N, Wu WJ, Yuan F, O'Brien E, Wang T, Luo L, Hunt GN, Zhu X, Bolli R (2011) Intracoronary administration of cardiac stem cells in mice: a new, improved technique for cell therapy in murine models. Basic Res Cardiol 106:849-864. doi:10.1007/s00395-011-0180-1 
5. Hong KU, Guo Y, Li QH, Cao P, Al-Maqtari T, Vajravelu BN, Du J, Book MJ, Zhu X, Nong Y, Bhatnagar A, Bolli R (2014) c-kit + Cardiac stem cells alleviate post-myocardial infarction left ventricular dysfunction despite poor engraftment and negligible retention in the recipient heart. PLoS One 9:e96725. doi:10.1371/journal.pone.0096725

6. Tang XL, Rokosh G, Sanganalmath SK, Yuan F, Sato H, Mu J, Dai S, Li C, Chen N, Peng Y, Dawn B, Hunt G, Leri A, Kajstura J, Tiwari S, Shirk G, Anversa P, Bolli R (2010) Intracoronary administration of cardiac progenitor cells alleviates left ventricular dysfunction in rats with a 30-day-old infarction. Circulation 121:293-305. doi:10.1161/circulationaha.109.871905

7. Tang XL, Rokosh G, Sanganalmath SK, Tokita Y, Keith MC, Shirk G, Stowers H, Hunt GN, Wu W, Dawn B, Bolli R (2015) Effects of Intracoronary Infusion of Escalating Doses of Cardiac Stem Cells in Rats With Acute Myocardial Infarction. Circ Heart Fail 8:757-765.

doi:10.1161/circheartfailure.115.002210

8. Tang XL, Li Q, Rokosh G, Sanganalmath SK, Chen N, Ou Q, Stowers H, Hunt G, Bolli R (2016) LongTerm Outcome of Administration of c-kit(POS) Cardiac Progenitor Cells After Acute Myocardial Infarction: Transplanted Cells Do not Become Cardiomyocytes, but Structural and Functional Improvement and Proliferation of Endogenous Cells Persist for at Least One Year. Circ Res 118:1091-1105. doi:10.1161/CIRCRESAHA.115.307647

9. Tokita Y, Tang XL, Li Q, Wysoczynski M, Hong KU, Nakamura S, Wu WJ, Xie W, Li D, Hunt G, Ou Q, Stowers H, Bolli R (2016) Repeated Administrations of Cardiac Progenitor Cells Are Markedly More Effective Than a Single Administration: A New Paradigm in Cell Therapy. Circ Res 119:635-651. doi:10.1161/circresaha.116.308937

10. Tang XL, Nakamura S, Li Q, Wysoczynski M, Gumpert AM, Wu WJ, Hunt G, Stowers H, Ou Q, Bolli R (2018) Repeated Administrations of Cardiac Progenitor Cells Are Superior to a Single Administration of an Equivalent Cumulative Dose. J Am Heart Assoc 7. doi:10.1161/jaha.117.007400

11. Bolli R, Tang XL, Sanganalmath SK, Rimoldi O, Mosna F, Abdel-Latif A, Jneid H, Rota M, Leri A, Kajstura J (2013) Intracoronary delivery of autologous cardiac stem cells improves cardiac function in a porcine model of chronic ischemic cardiomyopathy. Circulation 128:122-131. doi:10.1161/circulationaha.112.001075

12. Wysoczynski M, Guo Y, Moore JBt, Muthusamy S, Li Q, Nasr M, Li H, Nong Y, Wu W, Tomlin AA, Zhu X, Hunt G, Gumpert AM, Book MJ, Khan A, Tang XL, Bolli R (2017) Myocardial Reparative Properties of Cardiac Mesenchymal Cells Isolated on the Basis of Adherence. J Am Coll Cardiol 69:1824-1838. doi:10.1016/j.jacc.2017.01.048

13. Heidel JS, Fischer AG, Tang XL, Sadri G, Wu WJ, Moisa CR, Stowers H, Sandella N, Wysoczynski M, Uchida S, Moore Iv JB (2020) The Effect of Cardiogenic Factors on Cardiac Mesenchymal Cell AntiFibrogenic Paracrine Signaling and Therapeutic Performance. Theranostics 10:1514-1530. doi:10.7150/thno.41000

14. Moore JBt, Tang XL, Zhao J, Fischer AG, Wu WJ, Uchida S, Gumpert AM, Stowers H, Wysoczynski M, Bolli R (2018) Epigenetically modified cardiac mesenchymal stromal cells limit myocardial fibrosis 
and promote functional recovery in a model of chronic ischemic cardiomyopathy. Basic Res Cardiol 114:3. doi:10.1007/s00395-018-0710-1

15. Dawn B, Stein AB, Urbanek K, Rota M, Whang B, Rastaldo R, Torella D, Tang XL, Rezazadeh A, Kajstura J, Leri A, Hunt G, Varma J, Prabhu SD, Anversa P, Bolli R (2005) Cardiac stem cells delivered intravascularly traverse the vessel barrier, regenerate infarcted myocardium, and improve cardiac function. Proc Natl Acad Sci U S A 102:3766-3771. doi:10.1073/pnas.0405957102

16. Li Q, Bolli R, Qiu Y, Tang XL, Guo Y, French BA (2001) Gene therapy with extracellular superoxide dismutase protects conscious rabbits against myocardial infarction. Circulation 103:1893-1898. doi:10.1161/01.cir.103.14.1893

17. Tang XL, Qiu Y, Park SW, Sun JZ, Kalya A, Bolli R (1996) Time course of late preconditioning against myocardial stunning in conscious pigs. Circ Res 79:424-434. doi:10.1161/01.res.79.3.424

18. Li RC, Ping P, Zhang J, Wead WB, Cao X, Gao J, Zheng Y, Huang S, Han J, Bolli R (2000) PKCepsilon modulates NF-kappaB and AP-1 via mitogen-activated protein kinases in adult rabbit cardiomyocytes. Am J Physiol Heart Circ Physiol 279:H1679-H1689. doi:10.1152/ajpheart.2000.279.4.H1679

19. Takano H, Bolli R, Black RG Jr, Kodani E, Tang XL, Yang Z, Bhattacharya S, Auchampach JA (2001) $A(1)$ or $A(3)$ adenosine receptors induce late preconditioning against infarction in conscious rabbits by different mechanisms. Circ Res 88:520-528. doi:10.1161/01.res.88.5.520

20. Lee RH, Pulin AA, Seo MJ, Kota DJ, Ylostalo J, Larson BL, Semprun-Prieto L, Delafontaine P, Prockop DJ (2009) Intravenous hMSCs improve myocardial infarction in mice because cells embolized in lung are activated to secrete the anti-inflammatory protein TSG-6. Cell Stem Cell 5:54-63. doi:10.1016/j.stem.2009.05.003

21. Luger D, Lipinski MJ, Westman PC, Glover DK, Dimastromatteo J, Frias JC, Albelda MT, Sikora S, Kharazi A, Vertelov G, Waksman R, Epstein SE (2017) Intravenously Delivered Mesenchymal Stem Cells: Systemic Anti-Inflammatory Effects Improve Left Ventricular Dysfunction in Acute Myocardial Infarction and Ischemic Cardiomyopathy. Circ Res 120:1598-1613. doi:10.1161/CIRCRESAHA.117.310599

22. Ma J, Ge J, Zhang S, Sun A, Shen J, Chen L, Wang K, Zou Y (2005) Time course of myocardial stromal cell-derived factor 1 expression and beneficial effects of intravenously administered bone marrow stem cells in rats with experimental myocardial infarction. Basic Res Cardiol 100:217-223. doi:10.1007/s00395-005-0521-z

23. Nagaya N, Fujii T, Iwase T, Ohgushi H, Itoh T, Uematsu M, Yamagishi M, Mori H, Kangawa K, Kitamura $S$ (2004) Intravenous administration of mesenchymal stem cells improves cardiac function in rats with acute myocardial infarction through angiogenesis and myogenesis. Am J Physiol Heart Circ Physiol 287:H2670-H2676. doi:10.1152/ajpheart.01071.2003

24. Wang W, Jiang Q, Zhang H, Jin P, Yuan X, Wei Y, Hu S (2011) Intravenous administration of bone marrow mesenchymal stromal cells is safe for the lung in a chronic myocardial infarction model. Regen Med 6:179-190. doi:10.2217/rme.10.104 
25. Tang YL, Zhu W, Cheng M, Chen L, Zhang J, Sun T, Kishore R, Phillips MI, Losordo DW, Qin G (2009) Hypoxic preconditioning enhances the benefit of cardiac progenitor cell therapy for treatment of myocardial infarction by inducing CXCR4 expression. Circ Res 104:1209-1216. doi:10.1161/circresaha.109.197723

26. Mazhari R, Hare JM (2012) Translational findings from cardiovascular stem cell research. Trends Cardiovasc Med 22:1-6. doi:10.1016/j.tcm.2012.05.017

27. Berry MF, Engler AJ, Woo YJ, Pirolli TJ, Bish LT, Jayasankar V, Morine KJ, Gardner TJ, Discher DE, Sweeney HL (2006) Mesenchymal stem cell injection after myocardial infarction improves myocardial compliance. Am J Physiol Heart Circ Physiol 290:H2196-H2203. doi:10.1152/ajpheart.01017.2005

28. Schuleri KH, Feigenbaum GS, Centola M, Weiss ES, Zimmet JM, Turney J, Kellner J, Zviman MM, Hatzistergos KE, Detrick B, Conte JV, McNiece I, Steenbergen C, Lardo AC, Hare JM (2009) Autologous mesenchymal stem cells produce reverse remodelling in chronic ischaemic cardiomyopathy. Eur Heart J 30:2722-2732. doi:10.1093/eurheartj/ehp265

29. Hare JM, Fishman JE, Gerstenblith G, DiFede Velazquez DL, Zambrano JP, Suncion VY, Tracy M, Ghersin E, Johnston PV, Brinker JA, Breton E, Davis-Sproul J, Schulman IH, Byrnes J, Mendizabal AM, Lowery MH, Rouy D, Altman P, Wong Po Foo C, Ruiz P, Amador A, Da Silva J, McNiece IK, Heldman AW, George R, Lardo A (2012) Comparison of allogeneic vs autologous bone marrow-derived mesenchymal stem cells delivered by transendocardial injection in patients with ischemic cardiomyopathy: the POSEIDON randomized trial. Jama 308:2369-2379. doi:10.1001/jama.2012.25321

30. Williams AR, Suncion VY, McCall F, Guerra D, Mather J, Zambrano JP, Heldman AW, Hare JM (2013) Durable scar size reduction due to allogeneic mesenchymal stem cell therapy regulates wholechamber remodeling. J Am Heart Assoc 2:e000140. doi:10.1161/jaha.113.000140

31. Williams AR, Hatzistergos KE, Addicott B, McCall F, Carvalho D, Suncion V, Morales AR, Da Silva J, Sussman MA, Heldman AW, Hare JM (2013) Enhanced effect of combining human cardiac stem cells and bone marrow mesenchymal stem cells to reduce infarct size and to restore cardiac function after myocardial infarction. Circulation 127:213-223. doi:10.1161/circulationaha.112.131110

32. Mathiasen AB, Qayyum AA, Jorgensen E, Helqvist S, Fischer-Nielsen A, Kofoed KF, Haack-Sorensen $M$, Ekblond A, Kastrup J (2015) Bone marrow-derived mesenchymal stromal cell treatment in patients with severe ischaemic heart failure: a randomized placebo-controlled trial (MSC-HF trial). Eur Heart $J$ 36:1744-1753. doi:10.1093/eurheartj/ehv136

33. Karantalis V, Suncion-Loescher VY, Bagno L, Golpanian S, Wolf A, Sanina C, Premer C, Kanelidis AJ, McCall F, Wang B, Balkan W, Rodriguez J, Rosado M, Morales A, Hatzistergos K, Natsumeda M, Margitich I, Schulman IH, Gomes SA, Mushtaq M, DiFede DL, Fishman JE, Pattany P, Zambrano JP, Heldman AW, Hare JM (2015) Synergistic Effects of Combined Cell Therapy for Chronic Ischemic Cardiomyopathy. J Am Coll Cardiol 66:1990-1999. doi:10.1016/j.jacc.2015.08.879 
34. de Morais Sdel B, da Silva LE, Lataro RM, Silva CA, de Oliveira LF, de Carvalho EE, Simoes MV, da Silva Meirelles L, Fazan R Jr, Salgado HC (2015) Mesenchymal Stem Cells Improve Heart Rate Variability and Baroreflex Sensitivity in Rats with Chronic Heart Failure. Stem Cells Dev 24:21812192. doi:10.1089/scd.2014.0573

35. Natsumeda M, Florea V, Rieger AC, Tompkins BA, Banerjee MN, Golpanian S, Fritsch J, Landin AM, Kashikar ND, Karantalis V, Loescher VY, Hatzistergos KE, Bagno L, Sanina C, Mushtaq M, Rodriguez J, Rosado M, Wolf A, Collon K, Vincent L, Kanelidis AJ, Schulman IH, Mitrani R, Heldman AW, Balkan W, Hare JM (2017) A Combination of Allogeneic Stem Cells Promotes Cardiac Regeneration. J Am Coll Cardiol 70:2504-2515. doi:10.1016/j.jacc.2017.09.036

36. Kim SH, Cho JH, Lee YH, Lee JH, Kim SS, Kim MY, Lee MG, Kang WY, Lee KS, Ahn YK, Jeong MH, Kim HS (2018) Improvement in Left Ventricular Function with Intracoronary Mesenchymal Stem Cell Therapy in a Patient with Anterior Wall ST-Segment Elevation Myocardial Infarction. CardiovasC Drugs Ther. doi:10.1007/s10557-018-6804-z

37. Wysoczynski M, Dassanayaka S, Zafir A, Ghafghazi S, Long BW, Noble C, DeMartino AM, Brittian KR, Bolli R, Jones SP (2016) A New Method to Stabilize C-Kit Expression in Reparative Cardiac Mesenchymal Cells. Front Cell Dev Biol 4:78. doi:10.3389/fcell.2016.00078

38. Guo Y, Wysoczynski M, Nong Y, Tomlin A, Zhu X, Gumpert AM, Nasr M, Muthusamy S, Li H, Book M, Khan A, Hong KU, Li Q, Bolli R (2017) Repeated doses of cardiac mesenchymal cells are therapeutically superior to a single dose in mice with old myocardial infarction. Basic Res Cardiol 112:18. doi:10.1007/s00395-017-0606-5

39. Guo Y, Nong Y, Li Q, Tomlin A, Kahlon A, Gumpert A, Slezak J, Zhu X, Bolli R (2021) Comparison of One and Three Intraventricular Injections of Cardiac Progenitor Cells in a Murine Model of Chronic Ischemic Cardiomyopathy. Stem Cell Rev Rep 17:604-615. doi:10.1007/s12015-020-10063-0

40. Avolio E, Meloni M, Spencer HL, Riu F, Katare R, Mangialardi G, Oikawa A, Rodriguez-Arabaolaza I, Dang Z, Mitchell K, Reni C, Alvino VV, Rowlinson J, Livi U, Cesselli D, Angelini G, Emanueli C, Beltrami AP, Madeddu P (2015) Combined intramyocardial delivery of human pericytes and cardiac stem cells additively improves the healing of mouse infarcted hearts through stimulation of vascular and muscular repair. Circ Res 116:e81-e94. doi:10.1161/circresaha.115.306146

41. Cai C, Guo Y, Teng L, Nong Y, Tan M, Book MJ, Zhu X, Wang XL, Du J, Wu WJ, Xie W, Hong KU, Li Q, Bolli R (2015) Preconditioning Human Cardiac Stem Cells with an HO-1 Inducer Exerts Beneficial Effects After Cell Transplantation in the Infarcted Murine Heart. Stem Cells 33:3596-3607. doi:10.1002/stem.2198

42. Duran JM, Makarewich CA, Sharp TE, Starosta T, Zhu F, Hoffman NE, Chiba Y, Madesh M, Berretta RM, Kubo H, Houser SR (2013) Bone-derived stem cells repair the heart after myocardial infarction through transdifferentiation and paracrine signaling mechanisms. Circ Res 113:539-552. doi:10.1161/circresaha.113.301202

43. Fischer KM, Cottage CT, Wu W, Din S, Gude NA, Avitabile D, Quijada P, Collins BL, Fransioli J, Sussman MA (2009) Enhancement of myocardial regeneration through genetic engineering of 
cardiac progenitor cells expressing Pim-1 kinase. Circulation 120:2077-2087.

doi:10.1161/circulationaha.109.884403

44. Kazakov A, Meier T, Werner C, Hall R, Klemmer B, Körbel C, Lammert F, Maack C, Böhm M, Laufs U (2015) C-kit(+) resident cardiac stem cells improve left ventricular fibrosis in pressure overload. Stem Cell Res 15:700-711. doi:10.1016/j.scr.2015.10.017

45. Li TS, Cheng K, Malliaras K, Smith RR, Zhang Y, Sun B, Matsushita N, Blusztajn A, Terrovitis J, Kusuoka H, Marbán L, Marbán E (2012) Direct comparison of different stem cell types and subpopulations reveals superior paracrine potency and myocardial repair efficacy with cardiospherederived cells. J Am Coll Cardiol 59:942-953. doi:10.1016/j.jacc.2011.11.029

46. Li W, Lu Y, Han R, Yue Q, Song X, Wang F, Wu R, Hou F, Yang L, Xu L, Zhao R, Hu J (2018) Gremlin2 Regulates the Differentiation and Function of Cardiac Progenitor Cells via the Notch Signaling Pathway. Cell Physiol Biochem 47:579-589. doi:10.1159/000490012

47. Ma W, Ding F, Wang X, Huang Q, Zhang L, Bi C, Hua B, Yuan Y, Han Z, Jin M, Liu T, Yu Y, Cai B, Du Z (2018) By Targeting Atg7 MicroRNA-143 Mediates Oxidative Stress-Induced Autophagy of C-Kit(+) Mouse Cardiac Progenitor Cells. EBioMedicine 32:182-191. doi:10.1016/j.ebiom.2018.05.021

48. Ma W, He F, Ding F, Zhang L, Huang Q, Bi C, Wang X, Hua B, Yang F, Yuan Y, Han Z, Jin M, Liu T, Yu Y, Cai B, Lu Y, Du Z (2018) Pre-Treatment with Melatonin Enhances Therapeutic Efficacy of Cardiac Progenitor Cells for Myocardial Infarction. Cell Physiol Biochem 47:1287-1298. doi:10.1159/000490224

49. Mohsin S, Khan M, Toko H, Bailey B, Cottage CT, Wallach K, Nag D, Lee A, Siddiqi S, Lan F, Fischer KM, Gude N, Quijada P, Avitabile D, Truffa S, Collins B, Dembitsky W, Wu JC, Sussman MA (2012) Human cardiac progenitor cells engineered with Pim-I kinase enhance myocardial repair. J Am Coll Cardiol 60:1278-1287. doi:10.1016/j.jacc.2012.04.047

50. Oskouei BN, Lamirault G, Joseph C, Treuer AV, Landa S, Da Silva J, Hatzistergos K, Dauer M, Balkan W, McNiece I, Hare JM (2012) Increased potency of cardiac stem cells compared with bone marrow mesenchymal stem cells in cardiac repair. Stem Cells Transl Med 1:116-124.

doi:10.5966/sctm.2011-0015

51. Puddighinu G, D'Amario D, Foglio E, Manchi M, Siracusano A, Pontemezzo E, Cordella M, Facchiano F, Pellegrini L, Mangoni A, Tafani M, Crea F, Germani A, Russo MA, Limana F (2018) Molecular mechanisms of cardioprotective effects mediated by transplanted cardiac ckit(+) cells through the activation of an inflammatory hypoxia-dependent reparative response. Oncotarget 9:937-957. doi:10.18632/oncotarget.22946

52. Wang K, Zhao X, Kuang C, Qian D, Wang H, Jiang H, Deng M, Huang L (2012) Overexpression of SDF$1 \mathrm{a}$ enhanced migration and engraftment of cardiac stem cells and reduced infarcted size via CXCR4/PI3K pathway. PLoS One 7:e43922. doi:10.1371/journal.pone.0043922

53. Zhang LX, DeNicola M, Qin X, Du J, Ma J, Tina Zhao Y, Zhuang S, Liu PY, Wei L, Qin G, Tang Y, Zhao TC (2014) Specific inhibition of HDAC4 in cardiac progenitor cells enhances myocardial repairs. Am J Physiol Cell Physiol 307:C358-C372. doi:10.1152/ajpcell.00187.2013 
54. Zhao YT, Du J, Chen Y, Tang Y, Qin G, Lv G, Zhuang S, Zhao TC (2015) Inhibition of Oct 3/4 mitigates the cardiac progenitor-derived myocardial repair in infarcted myocardium. Stem Cell Res Ther 6:259. doi:10.1186/s13287-015-0252-5

55. Alshammary S, Fukushima S, Miyagawa S, Matsuda T, Nishi H, Saito A, Kamata S, Asahara T, Sawa Y (2013) Impact of cardiac stem cell sheet transplantation on myocardial infarction. Surg Today 43:970-976. doi:10.1007/s00595-013-0528-2

56. Bao L, Meng Q, Li Y, Deng S, Yu Z, Liu Z, Zhang L, Fan H (2017) C-Kit Positive Cardiac Stem Cells and Bone Marrow-Derived Mesenchymal Stem Cells Synergistically Enhance Angiogenesis and Improve Cardiac Function After Myocardial Infarction in a Paracrine Manner. J Card Fail 23:403-415. doi:10.1016/j.cardfail.2017.03.002

57. Bhutani S, Nachlas ALY, Brown ME, Pete T, Johnson CT, García AJ, Davis ME (2018) Evaluation of Hydrogels Presenting Extracellular Matrix-Derived Adhesion Peptides and Encapsulating Cardiac Progenitor Cells for Cardiac Repair. ACS Biomater Sci Eng 4:200-210. doi:10.1021/acsbiomaterials.7b00502

58. Carr CA, Stuckey DJ, Tan JJ, Tan SC, Gomes RS, Camelliti P, Messina E, Giacomello A, Ellison GM, Clarke K (2011) Cardiosphere-derived cells improve function in the infarcted rat heart for at least 16 weeks-an MRI study. PLoS One 6:e25669. doi:10.1371/journal.pone.0025669

59. Dergilev K, Tsokolaeva Z, Makarevich P, Beloglazova I, Zubkova E, Boldyreva M, Ratner E, Dyikanov D, Menshikov M, Ovchinnikov A, Ageev F, Parfyonova Y (2018) C-Kit Cardiac Progenitor Cell Based Cell Sheet Improves Vascularization and Attenuates Cardiac Remodeling following Myocardial Infarction in Rats. Biomed Res Int 2018:3536854. doi:10.1155/2018/3536854

60. Ellison GM, Vicinanza C, Smith AJ, Aquila I, Leone A, Waring CD, Henning BJ, Stirparo GG, Papait R, Scarfò M, Agosti V, Viglietto G, Condorelli G, Indolfi C, Ottolenghi S, Torella D, Nadal-Ginard B (2013) Adult c-kit(pos) cardiac stem cells are necessary and sufficient for functional cardiac regeneration and repair. Cell 154:827-842. doi:10.1016/j.cell.2013.07.039

61. Li C, Matsushita S, Li Z, Guan J, Amano A (2017) c-kit Positive Cardiac Outgrowth Cells Demonstrate Better Ability for Cardiac Recovery Against Ischemic Myopathy. J Stem Cell Res Ther 7. doi:10.4172/2157-7633.1000402

62. Matsuda T, Miyagawa S, Fukushima S, Kitagawa-Sakakida S, Akimaru H, Horii-Komatsu M, Kawamoto A, Saito A, Asahara T, Sawa Y (2014) Human cardiac stem cells with reduced notch signaling show enhanced therapeutic potential in a rat acute infarction model. Circ J 78:222-231. doi:10.1253/circj.cj-13-0534

63. Maxwell JT, Trac D, Shen M, Brown ME, Davis ME, Chao MS, Supapannachart KJ, Zaladonis CA, Baker E, Li ML, Zhao J, Jacobs DI (2019) Electrical Stimulation of pediatric cardiac-derived c-kit(+) progenitor cells improves retention and cardiac function in right ventricular heart failure. Stem Cells 37:1528-1541. doi:10.1002/stem.3088

64. Sharma S, Mishra R, Simpson D, Wehman B, Colletti EJ, Deshmukh S, Datla SR, Balachandran K, Guo Y, Chen L, Siddiqui OT, Kaushal S, Kaushal S (2015) Cardiosphere-derived cells from pediatric end- 
stage heart failure patients have enhanced functional activity due to the heat shock response regulating the secretome. Stem Cells 33:1213-1229. doi:10.1002/stem.1937

65. Simpson DL, Mishra R, Sharma S, Goh SK, Deshmukh S, Kaushal S (2012) A strong regenerative ability of cardiac stem cells derived from neonatal hearts. Circulation 126:S46-S53. doi:10.1161/circulationaha.111.084699

66. Tang JM, Luo B, Xiao JH, Lv YX, Li XL, Zhao JH, Zheng F, Zhang L, Chen L, Yang JY, Guo LY, Wang L, Yan YW, Pan YM, Wang JN, Li DS, Wan Y, Chen SY (2015) VEGF-A promotes cardiac stem cell engraftment and myocardial repair in the infarcted heart. Int $\mathrm{J}$ Cardiol 183:221-231. doi:10.1016/j.ijcard.2015.01.050

67. Vahdat S, Mousavi SA, Omrani G, Gholampour M, Sotoodehnejadnematalahi F, Ghazizadeh Z, Gharechahi J, Baharvand H, Salekdeh GH, Aghdami N (2015) Cellular and molecular characterization of human cardiac stem cells reveals key features essential for their function and safety. Stem Cells Dev 24:1390-1404. doi:10.1089/scd.2014.0222

68. Vicinanza C, Aquila I, Scalise M, Cristiano F, Marino F, Cianflone E, Mancuso T, Marotta P, Sacco W, Lewis FC, Couch L, Shone V, Gritti G, Torella A, Smith AJ, Terracciano CM, Britti D, Veltri P, Indolfi C, Nadal-Ginard B, Ellison-Hughes GM, Torella D (2017) Adult cardiac stem cells are multipotent and robustly myogenic: c-kit expression is necessary but not sufficient for their identification. Cell Death Differ 24:2101-2116. doi:10.1038/cdd.2017.130

69. Zakharova L, Nural-Guvener H, Feehery L, Popovic S, Nimlos J, Gaballa MA (2014) Retrograde coronary vein infusion of cardiac explant-derived c-Kit + cells improves function in ischemic heart failure. J Heart Lung Transplant 33:644-653. doi:10.1016/j.healun.2014.03.006

70. Zakharova L, Nural-Guvener H, Feehery L, Popovic-Sljukic S, Gaballa MA (2015) Transplantation of Epigenetically Modified Adult Cardiac c-Kit + Cells Retards Remodeling and Improves Cardiac Function in Ischemic Heart Failure Model. Stem Cells Transl Med 4:1086-1096. doi:10.5966/sctm.2014-0290

71. Zhang Z, Yang J, Yan W, Li Y, Shen Z, Asahara T (2016) Pretreatment of Cardiac Stem Cells With Exosomes Derived From Mesenchymal Stem Cells Enhances Myocardial Repair. J Am Heart Assoc 5. doi:10.1161/jaha.115.002856

72. Welt FG, Gallegos R, Connell J, Kajstura J, D'Amario D, Kwong RY, Coelho-Filho O, Shah R, Mitchell R, Leri A, Foley L, Anversa P, Pfeffer MA (2013) Effect of cardiac stem cells on left-ventricular remodeling in a canine model of chronic myocardial infarction. Circ Heart Fail 6:99-106. doi:10.1161/circheartfailure.112.972273

73. Kamata S, Miyagawa S, Fukushima S, Nakatani S, Kawamoto A, Saito A, Harada A, Shimizu T, Daimon T, Okano T, Asahara T, Sawa Y (2014) Improvement of cardiac stem cell sheet therapy for chronic ischemic injury by adding endothelial progenitor cell transplantation: analysis of layerspecific regional cardiac function. Cell Transplant 23:1305-1319. doi:10.3727/096368913×665602

74. Kulandavelu S, Karantalis V, Fritsch J, Hatzistergos KE, Loescher VY, McCall F, Wang B, Bagno L, Golpanian S, Wolf A, Grenet J, Williams A, Kupin A, Rosenfeld A, Mohsin S, Sussman MA, Morales A, 
Balkan W, Hare JM (2016) Pim1 Kinase Overexpression Enhances ckit(+) Cardiac Stem Cell Cardiac Repair Following Myocardial Infarction in Swine. J Am Coll Cardiol 68:2454-2464. doi:10.1016/j.jacc.2016.09.925

75. Wehman B, Pietris N, Bigham G, Siddiqui O, Mishra R, Li T, Aiello E, Jack G, Wang W, Murthi S, Sharma S, Kaushal S (2017) Cardiac Progenitor Cells Enhance Neonatal Right Ventricular Function After Pulmonary Artery Banding. Ann Thorac Surg 104:2045-2053. doi:10.1016/j.athoracsur.2017.04.058

76. Bolli R, Mitrani RD, Hare JM, Pepine CJ, Perin EC, Willerson JT, Traverse JH, Henry TD, Yang PC, Murphy MP, March KL, Schulman IH, Ikram S, Lee DP, O'Brien C, Lima JA, Ostovaneh MR, AmbaleVenkatesh B, Lewis G, Khan A, Bacallao K, Valasaki K, Longsomboon B, Gee AP, Richman S, Taylor DA, Lai D, Sayre SL, Bettencourt J, Vojvodic RW, Cohen ML, Simpson L, Aguilar D, Loghin C, Moyé L, Ebert RF, Davis BR, Simari RD (2021) A Phase II study of autologous mesenchymal stromal cells and c-kit positive cardiac cells, alone or in combination, in patients with ischaemic heart failure: the CCTRN CONCERT-HF trial. Eur J Heart Fail. doi:10.1002/ejhf.2178

77. Chugh AR, Beache GM, Loughran JH, Mewton N, Elmore JB, Kajstura J, Pappas P, Tatooles A, Stoddard MF, Lima JA, Slaughter MS, Anversa P, Bolli R (2012) Administration of cardiac stem cells in patients with ischemic cardiomyopathy: the SCIPIO trial: surgical aspects and interim analysis of myocardial function and viability by magnetic resonance. Circulation 126:S54-S64. doi:10.1161/circulationaha.112.092627

78. Gnecchi M, He H, Liang OD, Melo LG, Morello F, Mu H, Noiseux N, Zhang L, Pratt RE, Ingwall JS, Dzau VJ (2005) Paracrine action accounts for marked protection of ischemic heart by Akt-modified mesenchymal stem cells. Nat Med 11:367-368. doi:10.1038/nm0405-367

79. Gnecchi M, Zhang Z, Ni A, Dzau VJ (2008) Paracrine mechanisms in adult stem cell signaling and therapy. Circ Res 103:1204-1219. doi:10.1161/circresaha.108.176826

80. Phinney DG, Prockop DJ (2007) Concise review: mesenchymal stem/multipotent stromal cells: the state of transdifferentiation and modes of tissue repair-current views. Stem Cells 25:2896-2902. doi:10.1634/stemcells.2007-0637

81. Bolli R (2017) Repeated Cell Therapy: A Paradigm Shift Whose Time Has Come. Circ Res 120:10721074. doi:10.1161/circresaha. 117.310710

82. Nguyen PK, Rhee JW, Wu JC (2016) Adult Stem Cell Therapy and Heart Failure, 2000 to 2016: A Systematic Review. JAMA Cardiol 1:831-841. doi:10.1001/jamacardio.2016.2225

83. Nauta AJ, Fibbe WE (2007) Immunomodulatory properties of mesenchymal stromal cells. Blood 110:3499-3506. doi:10.1182/blood-2007-02-069716

84. Hare JM, Traverse JH, Henry TD, Dib N, Strumpf RK, Schulman SP, Gerstenblith G, DeMaria AN, Denktas AE, Gammon RS, Hermiller JB Jr, Reisman MA, Schaer GL, Sherman W (2009) A randomized, double-blind, placebo-controlled, dose-escalation study of intravenous adult human mesenchymal stem cells (prochymal) after acute myocardial infarction. J Am Coll Cardiol 54:2277-2286. doi:10.1016/j.jacc.2009.06.055 
85. Boomsma RA, Swaminathan PD, Geenen DL (2007) Intravenously injected mesenchymal stem cells home to viable myocardium after coronary occlusion and preserve systolic function without altering infarct size. Int J Cardiol 122:17-28. doi:10.1016/j.ijcard.2006.11.022

86. Halkos ME, Zhao ZQ, Kerendi F, Wang NP, Jiang R, Schmarkey LS, Martin BJ, Quyyumi AA, Few WL, Kin H, Guyton RA, Vinten-Johansen J (2008) Intravenous infusion of mesenchymal stem cells enhances regional perfusion and improves ventricular function in a porcine model of myocardial infarction. Basic Res Cardiol 103:525-536. doi:10.1007/s00395-008-0741-0

87. Jiang W, Ma A, Wang T, Han K, Liu Y, Zhang Y, Dong A, Du Y, Huang X, Wang J, Lei X, Zheng X (2006) Homing and differentiation of mesenchymal stem cells delivered intravenously to ischemic myocardium in vivo: a time-series study. Pflugers Arch 453:43-52. doi:10.1007/s00424-006-0117-y

88. Krause U, Harter C, Seckinger A, Wolf D, Reinhard A, Bea F, Dengler T, Hardt S, Ho A, Katus HA, Kuecherer $\mathrm{H}$, Hansen A (2007) Intravenous delivery of autologous mesenchymal stem cells limits infarct size and improves left ventricular function in the infarcted porcine heart. Stem Cells Dev 16:31-37. doi:10.1089/scd.2006.0089

89. Lim M, Wang W, Liang L, Han ZB, Li Z, Geng J, Zhao M, Jia H, Feng J, Wei Z, Song B, Zhang J, Li J, Liu T, Wang F, Li T, Li J, Fang Y, Gao J, Han Z (2018) Intravenous injection of allogeneic umbilical cord-derived multipotent mesenchymal stromal cells reduces the infarct area and ameliorates cardiac function in a porcine model of acute myocardial infarction. Stem Cell Res Ther 9:129. doi:10.1186/s13287-018-0888-z

90. Price MJ, Chou CC, Frantzen M, Miyamoto T, Kar S, Lee S, Shah PK, Martin BJ, Lill M, Forrester JS, Chen PS, Makkar RR (2006) Intravenous mesenchymal stem cell therapy early after reperfused acute myocardial infarction improves left ventricular function and alters electrophysiologic properties. Int J Cardiol 111:231-239. doi:10.1016/j.jijcard.2005.07.036

91. Wolf D, Reinhard A, Seckinger A, Gross L, Katus HA, Hansen A (2009) Regenerative capacity of intravenous autologous, allogeneic and human mesenchymal stem cells in the infarcted pig myocardium-complicated by myocardial tumor formation. Scand Cardiovasc J 43:39-45. doi:10.1080/14017430802100280

92. Bartolucci J, Verdugo FJ, Gonzalez PL, Larrea RE, Abarzua E, Goset C, Rojo P, Palma I, Lamich R, Pedreros PA, Valdivia G, Lopez VM, Nazzal C, Alcayaga-Miranda F, Cuenca J, Brobeck MJ, Patel AN, Figueroa FE, Khoury M (2017) Safety and Efficacy of the Intravenous Infusion of Umbilical Cord Mesenchymal Stem Cells in Patients With Heart Failure: A Phase 1/2 Randomized Controlled Trial (RIMECARD Trial [Randomized Clinical Trial of Intravenous Infusion Umbilical Cord Mesenchymal Stem Cells on Cardiopathy]). Circ Res 121:1192-1204. doi:10.1161/CIRCRESAHA.117.310712

93. Butler J, Epstein SE, Greene SJ, Quyyumi AA, Sikora S, Kim RJ, Anderson AS, Wilcox JE, Tankovich NI, Lipinski MJ, Ko YA, Margulies KB, Cole RT, Skopicki HA, Gheorghiade M (2017) Intravenous Allogeneic Mesenchymal Stem Cells for Nonischemic Cardiomyopathy: Safety and Efficacy Results of a Phase II-A Randomized Trial. Circ Res 120:332-340. doi:10.1161/circresaha.116.309717 


\section{Experimental Protocol}

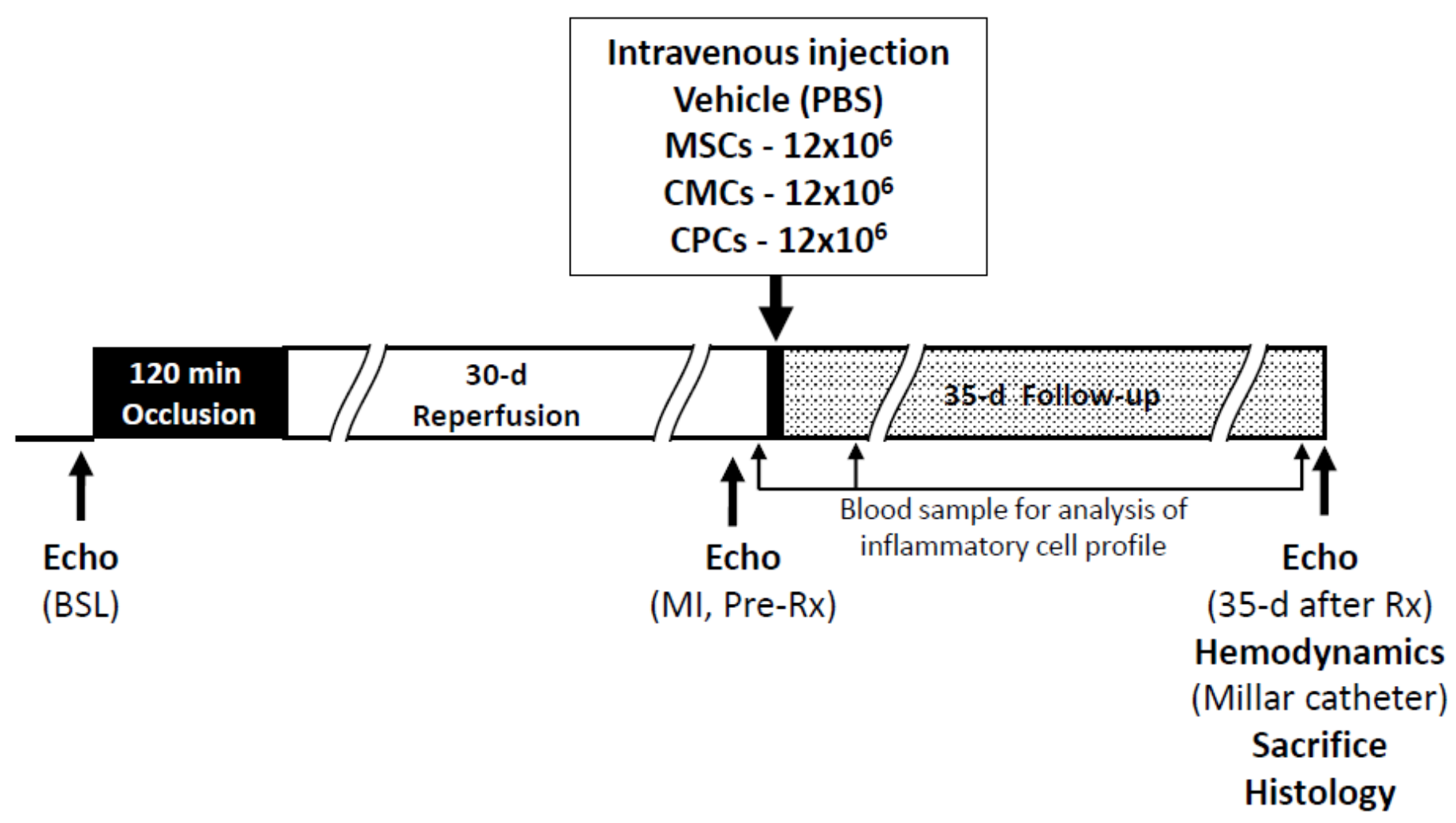

Figure 1

A: Experimental protocol. Echo, echocardiogram; PBS, Dulbecco's phosphate-buffered saline; MSCs, bone marrow-derived mesenchymal stromal cells; CMCs, cardiac mesenchymal cells; CPCs, c-kit-positive cardiac cells; Pre-Rx, pretreatment (30 days after MI). 
A

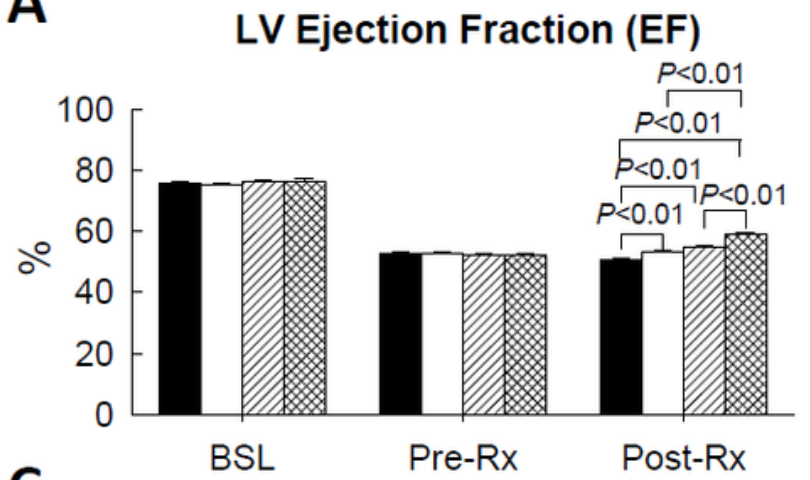

C

100

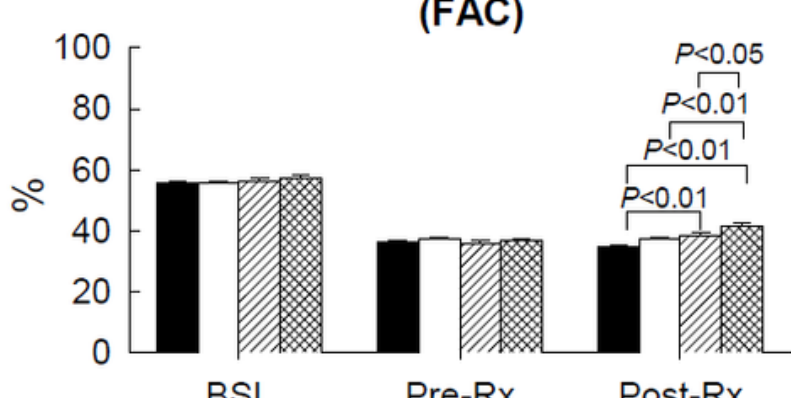

E

BSL

B

$\Delta \mathrm{EF}$ at $35 \mathrm{~d}$ Post-Rx vs. Pre-Rx

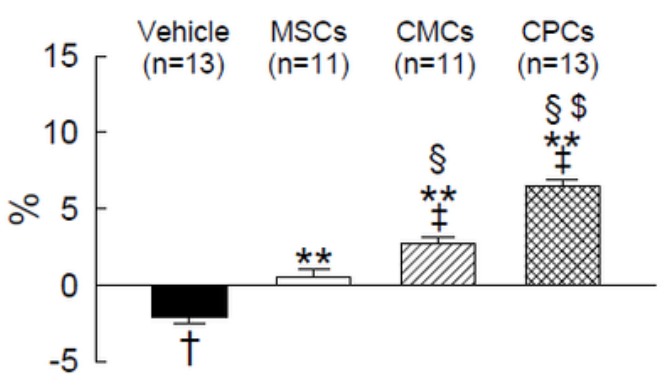

$D_{\triangle F A C}$ at 35 d Post-Rx vs. Pre-Rx

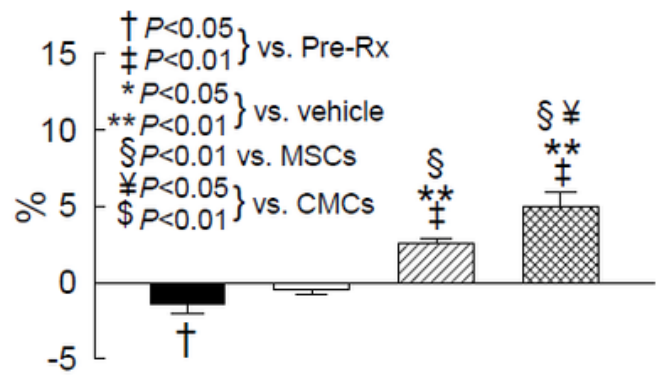

F ${ }_{\Delta \mathrm{ESV}}$ at $35 \mathrm{~d}$ Post-Rx vs. Pre-Rx

(ESV)
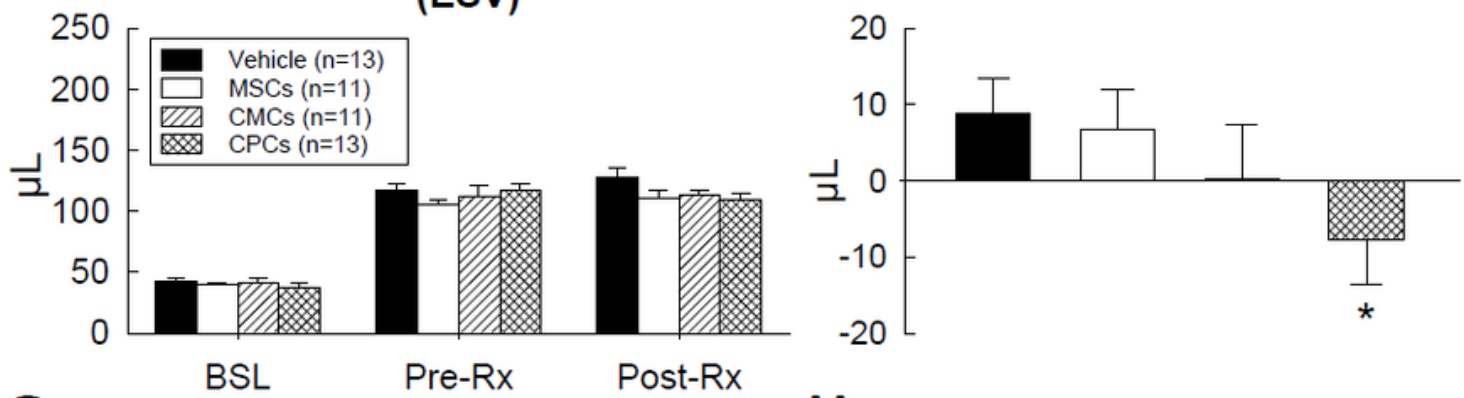

G

Stroke Volume (SV)

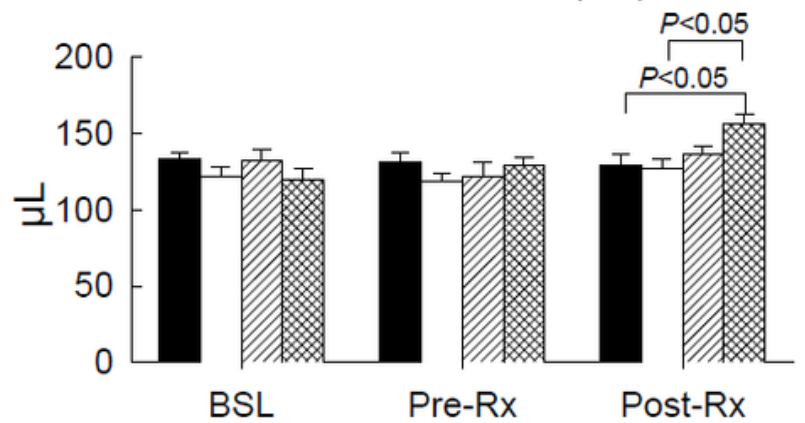

H $\Delta$ SV at 35 d Post-Rx vs. Pre-Rx

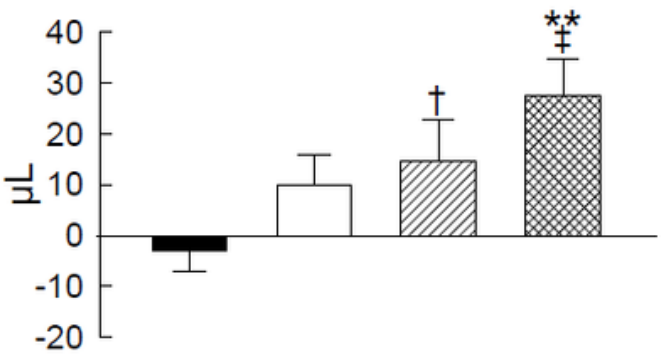

Figure 2

Echocardiographic assessment of LV function. Bar graph illustrating LV EF (A), FAC (C), ESV (E), and SV (G) at baseline (BSL), before treatment (Pre-Rx) (i.e., 30 days after $\mathrm{MI}$ ), and 35 days after the treatment (Post-Rx). $\Delta$ change (absolute units) in echocardiographic parameters at 35 days after treatment (Post$\mathrm{Rx}$ ) vs. pretreatment values (Pre-Rx): EF, ejection fraction (B); FAC, fractional area change (D); ESV, endsystolic volume $(F)$, and SV, stroke volume $(H)$. Data are means \pm SEM. 

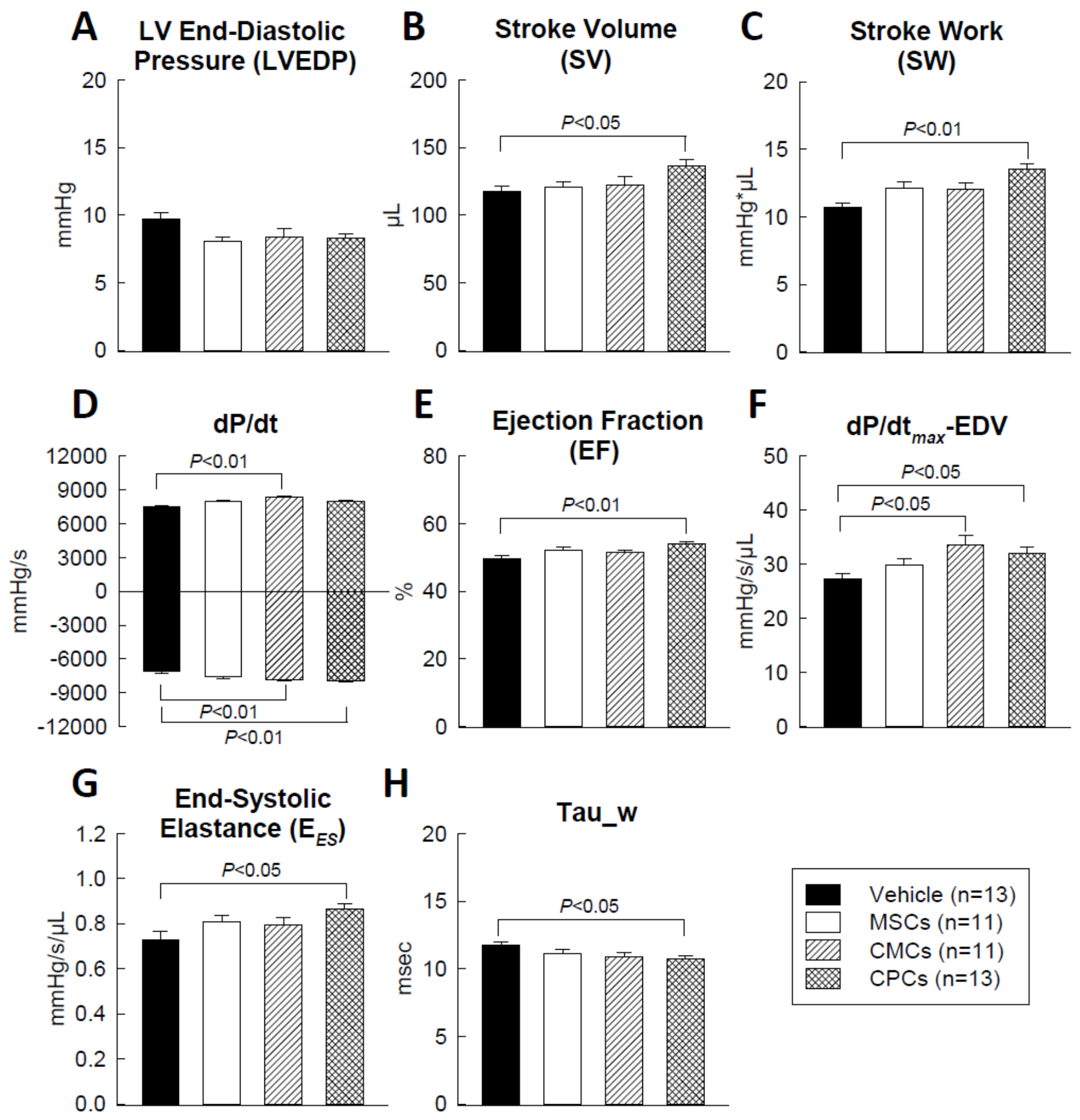

Figure 3

Hemodynamic assessment of LV function. Hemodynamic studies were performed with a Millar conductance catheter at 35 days after treatment, just before euthanasia. Quantitative analysis of hemodynamic variables: LV end-diastolic pressure (A), stroke volume (B), stroke work (C), dP/dt (D), ejection fraction $(E), d P / d t m a x-E D V(F)$, end-systolic elastance $(G)$ and tau_weiss $(H)$. Data are means \pm SEM. 
A Total LV weight (mg)

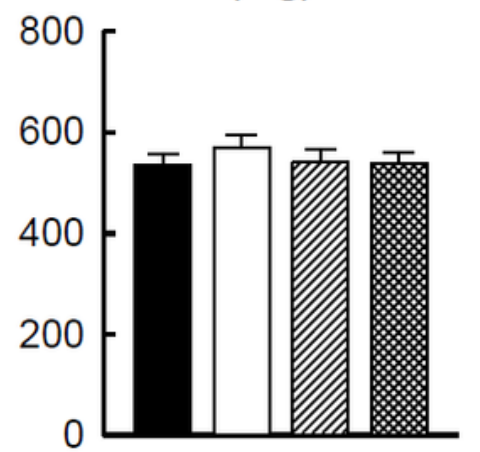

Risk Region

(\% of LV)

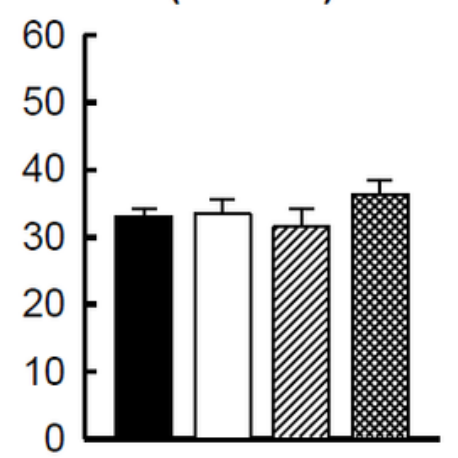

Scar

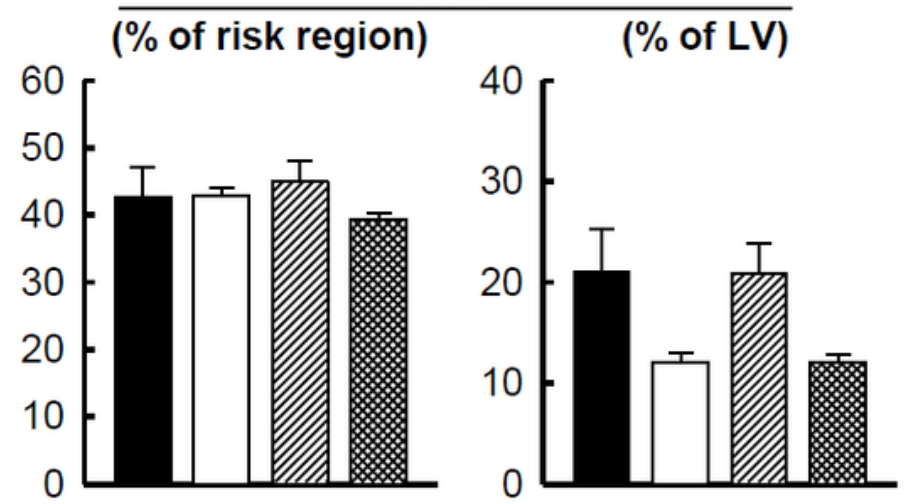

Viable Myocardium

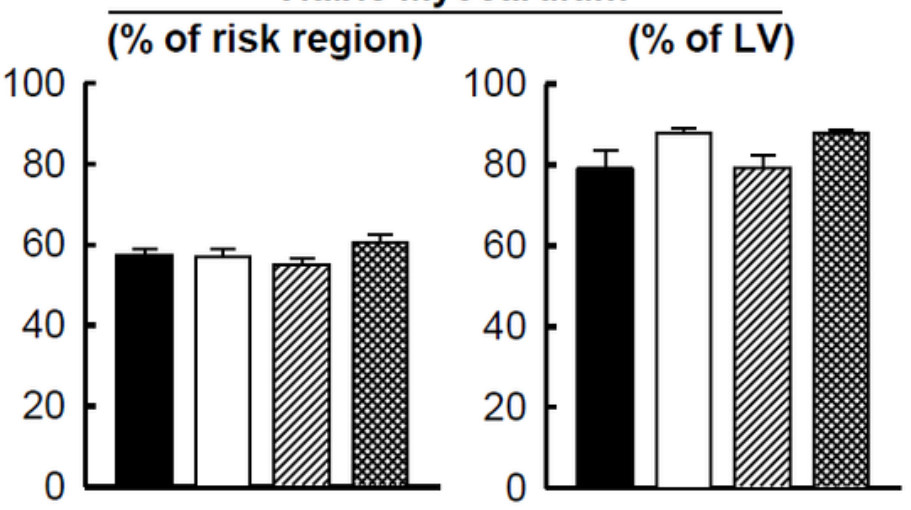

\section{B}

Risk region

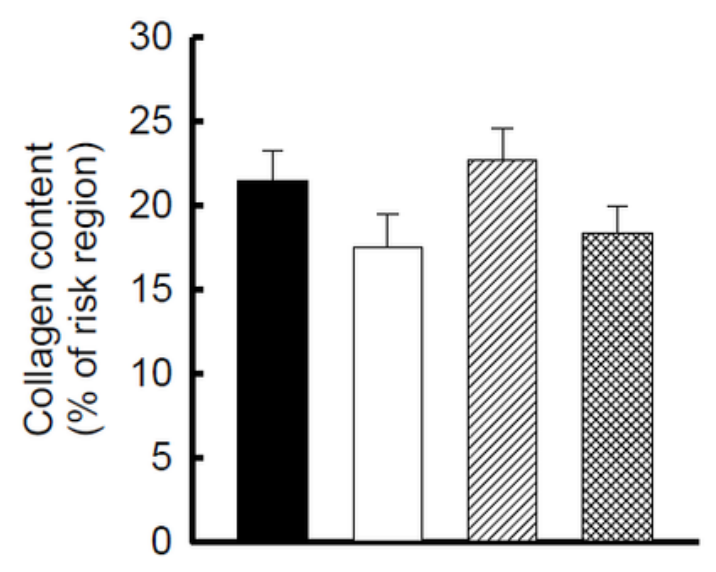

Noninfarcted region

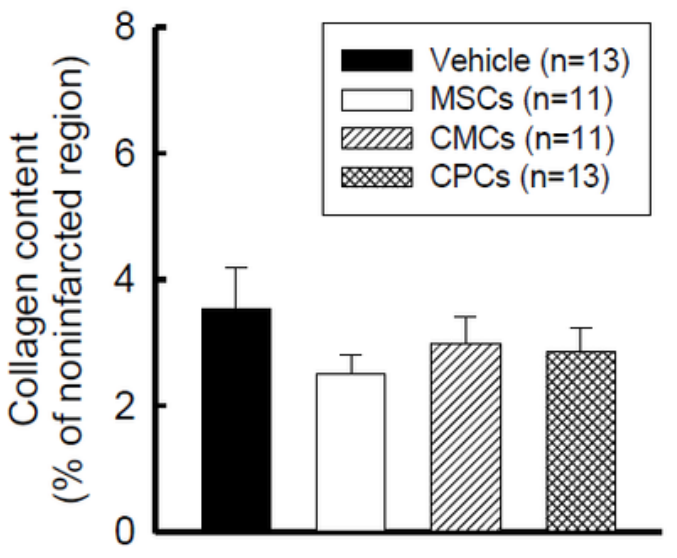

Figure 4

Morphometric analysis (A) and myocardial collagen content (B). A. Quantitative analysis of LV morphometric parameters. The risk region comprises both the border zones and the scarred region. $\mathrm{B}$. Quantitative analysis of polarized light microscopic images showing total collagen content as a percent of the risk and noninfarcted regions. Data are means \pm SEM. 
A Risk Region

B

Noninfarcted Region
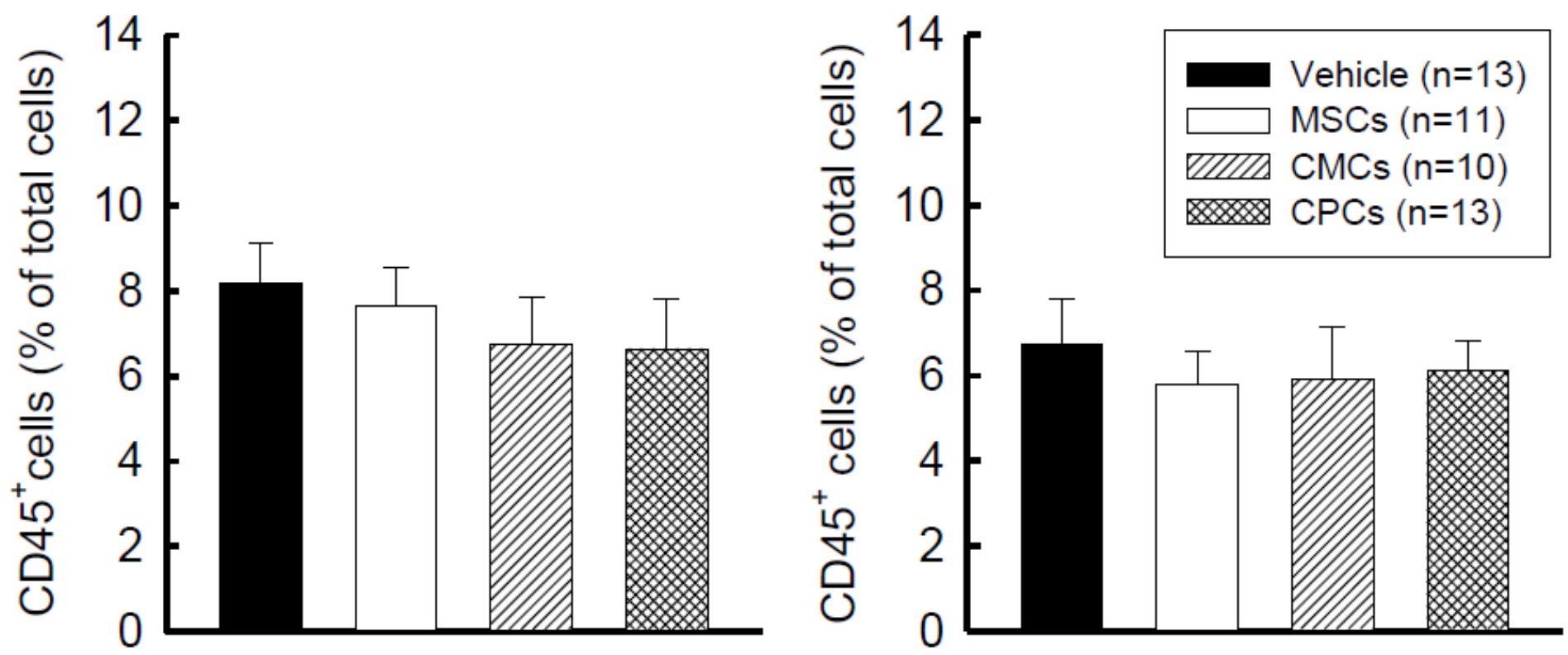

Figure 5

Myocardial content of CD45 positive cells. Quantitative analysis of CD45-positive cells was performed in the risk (border and infarcted region) and noninfarcted regions of the LV sections. Values are mean \pm SEM. 

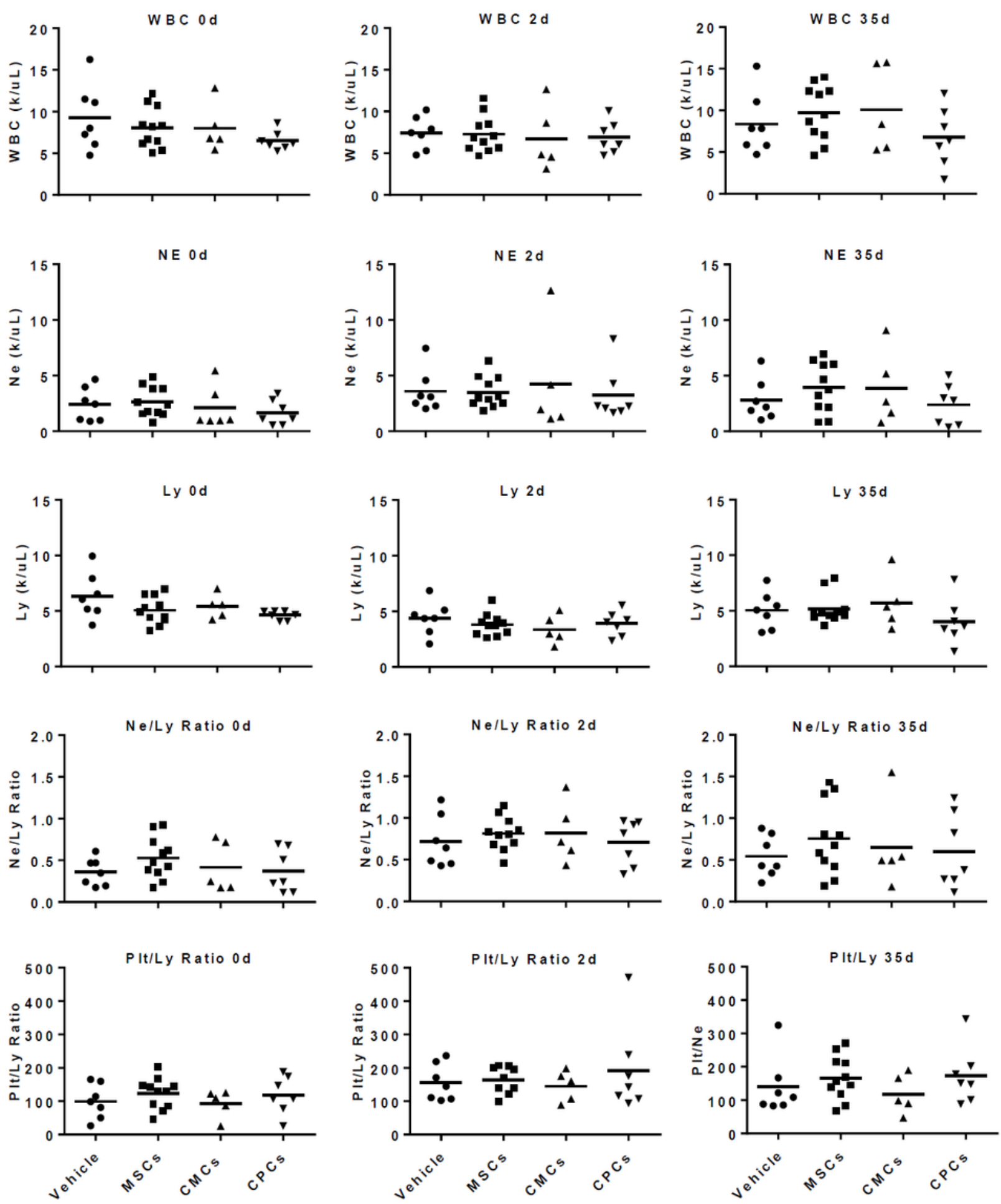

Figure 6

Hemavet analysis of inflammatory cells in the blood. Shown are WBCs, neutrophils (Ne), lymphocytes (Ly), the Ne/Ly ratio, and the platelet/Ly ratio at baseline (before cell infusion [0 d]), and $48 \mathrm{~h}(2 \mathrm{~d})$ and 35 days (35d) after intravenous infusion of vehicle (solid circles, $n=7$ ), MSCs (solid squares, $n=11$ ), CMCs (solid upward triangles, $n=5$ ), or CPCs (solid inverted triangles, $n=7$ ). Dots represent individual animals and bars represent means. 


\section{Supplementary Files}

This is a list of supplementary files associated with this preprint. Click to download.

- SupplementaryFiguresforlVCells06302021.pptx

- SupplementarytablesIVstudy06302021.docx 